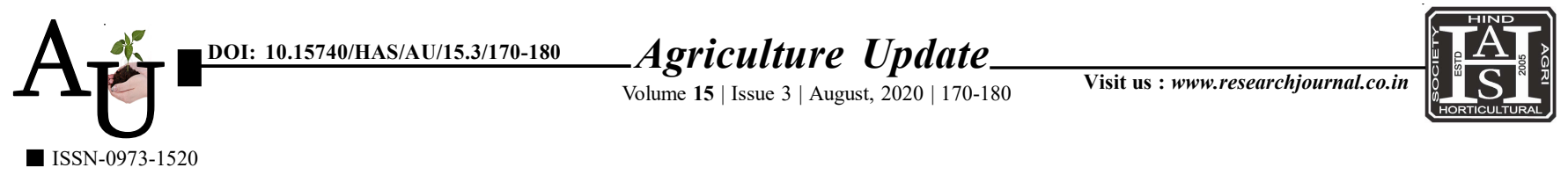

\title{
Research Article: Scale to measure utility perception of mass media by the farm women
}

Article Chronicle :

Received :

24.04.2020;

Revised:

06.06.2020;

Accepted :

08.07.2020

KEY Words :

Utility perception, Mass media, Farm women
Author for correspondence :

\section{R.P. Kadam}

Department of Extension

Education, College of

Agriculture, Vasantrao

Naik Marathwada Krishi

Vidyapeeth, Parbhani

(M.S.) India

Email: rpk.mkv@gmail.

com

See end of the article for

authors' affiliations

\section{A. S. Lad, P. R. Deshmukh and R. P. Kadam}

SUMMARY : Due to non-availability of proper scale to measure utility perception of mass media by the farm women, it was thought necessary to construct a scale for this purpose. Keeping this in view an attempt has been made to develop a scale for measuring utility perception of mass media by the farm women. Normalized rank approach recommended by Guilford (1978) was used in this study for scale construction.

How to cite this article : Lad, A.S., Deshmukh, P.R. and Kadam, R.P. (2020). Scale to measure utility perception of mass media by the farm women. Agric. Update, 15(3): 170-180; DOI : 10.15740/HAS/AU/15.3/170-180. Copyright@2020: Hind Agri-Horticultural Society. 